Revista Iberoamericana, Vol. LXXVIII, Núm. 241, Octubre-Diciembre 2012, 1043-1065

\title{
APUNTES SOBRE LA NOVELA LUMINOSA DE MARIO LEVRERO
}

\author{
POR \\ GABRIEL INZAURRALDE \\ Leiden University
}

Innumerables y repetidas son las peripecias domésticas que relata el "Diario de la beca”, la desmesurada introducción o prólogo a La novela luminosa de Mario Levrero. En el año 2000, el escritor recibe la beca Guggenheim para poder terminar una obra empezada una década antes. La sustancia de dicha novela inconclusa son una serie de experiencias singulares que el autor considera "luminosas". La beca es para poder completarla sin que la condición luminosa de esos relatos se pierda. Durante un año entero, el narrador Jorge Varlotta, verdadero nombre de Mario Levrero, escribe en su lugar una crónica cotidiana, personal aunque no íntima, un diario de 449 páginas que entre agosto del 2000 a agosto de 2001 da cuenta día a día y en primera persona de los hábitos, adicciones, estados de ánimo, lecturas y reflexiones del narrador. El diario se concibe como una forma de preparación, una operación de despeje y recuperación, para dar comienzo a la tarea principal: la escritura de la versión completa de la inconclusa novela luminosa. Se concibe entonces como una suerte de ejercicio de escritura, un entrenamiento. Pero finalmente se convertirá, junto con el texto matriz y de poco más de 100 páginas apenas modificado, en la novela propiamente dicha y publicada después de su muerte en el año 2005, es decir, lo que hoy conocemos como La novela luminosa de Mario Levrero. ${ }^{1}$

A estas primeras 449 páginas Levrero las llama el "Diario de la beca” y abunda en detalles cuya relevancia en principio resulta oscura. El diario nos muestra un Levrero ficcional relativamente confinado en su departamento de la Ciudad Vieja en Montevideo, entregado a la lectura voraz de novelas policiales de la colección Rastro. Lo visitan amigas diversas con las que sale a pasear (y a buscar novelas policiales) siguiendo siempre un idéntico trayecto, nunca más allá de la calle Ejido (que cruza 18 de julio). Lo visita periódicamente su ex esposa que además es su médica de cabecera y lo visita

1 Escribiré La novela luminosa, cuando me refiera a la novela en su totalidad y "La novela luminosa", cuando me refiera a las últimas cien páginas que llevan por título ese nombre. el "Diario de la beca” es el nombre que lleva la primera parte de la novela, su prólogo en forma de diario que abarca 450 páginas. G.I. 
Chl, su ex amante y pareja que al empezar el Diario ya ha empezado a dejar de serlo. ${ }^{2}$ Chl le trae milanesas y guisos y también lo acompaña en sus paseos. El narrador no sale casi nunca solo y el afuera urbano en general lo incomoda: los cambios decorativos de la intendencia, el miedo a la violencia, el acoso acústico de los altoparlantes, la música popular y la multitud, le producen un sentimiento de rechazo y vértigo. El diario registra meticulosamente sus noches insomnes, sus novelas policiales, su relación culpable con la pornografía y los juegos de computadora, las especulaciones sobre su medicación o sobre los efectos colaterales de sus tranquilizantes, sus ataques de pánico, su agorafobia, los cambios que realiza en su apartamento y cómo se va gastando el dinero de la beca Guggenheim sin avanzar un milímetro en el proyecto de la novela para el cual se la otorgaron. Leemos, finalmente, sobre la evolución escatológica de una paloma muerta en una azotea vecina que observa desde una ventana y comenta en forma casi cotidiana y el lento desenredarse de la relación sentimental entre el narrador y Chl.

El “Diario de la beca”, o sea el prólogo a la novela luminosa, está en el lugar de la novela propiamente dicha; es lo escrito mientras se aplaza indefinidamente el momento de empezarla o más bien de completarla. Las últimas cien páginas de la novela dan cuenta retrospectivamente de estas experiencias radicales. Allí un narrador aterrado por una venidera operación de vesícula se apresura a cartografiar la génesis y el acaecimiento de percepciones alucinadas, visiones o revelaciones que evidenciarían un mundo que, aunque invisible, condiciona todo lo existente. La novela luminosa es el "testimonio de un fracaso”, dice el propio Levrero en el prólogo (o prólogo de prólogos). Una novela esencialmente paradójica que recibe el título de lo que se confiesa no haber podido hacer.

Este sistema de escritura sobre el libro ausente, esta des-obra (en la terminología de Maurice Blanchot), forma una complicada secuencia con cuatro obras rioplatenses. El enervante relato “El escritor fracasado” (1997), de Roberto Arlt (con el que Levrero comparte la exploración de saberes esotéricos), trata sobre un aspirante a escritor que habla profusa y altaneramente de su futura novela en las tertulias literarias pero no consigue escribir una línea y termina convirtiéndose en un escritor sin obra, "un fracasado" y, finalmente, en un crítico implacable de sus colegas. En ese relato el personaje va superando etapas de envilecimiento, relacionadas al vencimiento de los plazos, a las dimensiones crecientes de un fracaso medido en semanas y meses de impotencia creativa. Aunque sin el aura maligna del personaje de Arlt, el "Diario de la beca" trabaja también sobre esta desesperación de escritor: la persona que debe un libro y por tanto carga con una deuda que, haga lo que haga, ensombrece sus días.

Por otra parte, La novela luminosa tiene también algo de la desmesura de los prólogos a Museo de la novela de la eterna (1967) de Macedonio Fernández, con quien

2 Chl. el sobrenombre que el autor elige para ocultar el verdadero nombre de su amante y es una contracción de "chica lista".

Revista Iberoamericana, Vol. LXXVIII, Núm. 241, Octubre-Diciembre 2012, 1043-1065
ISSN 0034-9631 (Impreso) 
Levrero comparte su desprecio por las convenciones genéricas y el hábito de la paradoja. Sólo que lo que antecede a los capítulos centrales de La novela luminosa no son sólo prólogos meditativos y provocadores sino también un diario personalísimo, a ratos confesional. En lo que respecta al uso del diario personal o íntimo como género, esta novela se emparienta con dos obras uruguayas: La tregua (1998) de Mario Benedetti y el Diario de un sinvergüenza (1983) de Felisberto Hernández. ${ }^{3}$ Con la primera la une la anotación melancólica de una historia crepuscular centrada también en las dificultades para asumir el ocio en la madurez y el fracaso de una relación sentimental aunque no comparte el patetismo de la narración de Benedetti. Con la segunda la une una voluntad de introspección con aire psicoanalítico, el humor, y el tema de la disociación entre lo que se propone la mente y lo que el cuerpo dispone. El personaje narrador de Levrero comparte también con el de Felisberto una lentitud característica, una torpeza o inadecuación respecto a la vida práctica y una inclinación congénita a la pereza y el análisis. De ambos el diario de Levrero se separa, no sólo por sus dimensiones, sino por la diversidad e indiferenciación de los materiales narrativos que exhibe y por la inclinación mística que recorre insistentemente su novela. El "Diario de la beca” es un informe pormenorizado de los días y sobre todo de las noches de Jorge Varlotta durante el año de la beca. En cierto sentido es, o simula ser, el testimonio de una cotidianidad desesperada, su relación con esa serie de momentos luminosos registrados años antes y el intento fallido de dotarlos de un contexto.

A pesar de la constante humorística que caracteriza toda la prosa del escritor, al final del diario se acentúa el tono elegíaco que termina predominando. El diario es el registro cotidiano de varias decadencias. La salud del narrador, siempre puesta en cuestión por él mismo (aunque aparentemente sin motivos reales), y la gradual pero irrevocable declinación de su relación sentimental con Chl, con la que ya no comparte sus noches. A medida que el diario avanza sin progresos girando en torno a la imposibilidad de desarrollar una historia, Chl se muestra cada vez más lejana, influida por su terapeuta que va ganándola a costa de su antiguo apego al narrador y con el convencido o resignado acuerdo de éste. Hacia el final, el control de las emociones derivado de esta tensión afectiva se descalabra y el narrador se confiesa a sí mismo que este diario es el registro de una depresión comenzada mucho antes (el día que Chl emprendió su primer largo viaje) y que el diario mismo, quizás, es un fatigoso duelo por la muchacha (422). La otra decadencia de la que el diario da concienzuda información es la de la gradual descomposición del cadáver de la paloma y de las extrañas visitas que éste recibe de su presunta viuda. El texto articula así la historia de esos días noctámbulos y solitarios

3 Sobre esto ha llamado la atención un interesante artículo de Hugo Verani (2006). Este artículo aparece mencionado en La novela luminosa, donde Levrero, amigablemente, discute con el crítico uruguayo transformándolo en personaje.

Revista Iberoamericana, Vol. LXXVIII, Núm. 241, Octubre-Diciembre 2012, 1043-1065 ISSN 0034-9631 (Impreso)

ISSN 2154-4794 (Electrónico) 
pasados en el departamento de Bartolomé Mitre con la melancólica vela en torno a un cadáver.

EL SUJETO INVOLUNTARIO

\begin{abstract}
¿Y la beca? Me imagino que un lector impertinente, de esos que nunca faltan, están pensando " ¿A este tipo le dieron un montón de plata para que juegue golf (y Buscaminas, reciente nuevo hábito) y se divierta con el Visual Basic? Qué desvergüenza. Y le llama 'Diario de la beca' ’”. Calma, lector. Me llevará tiempo cambiar los hábitos. (45)
\end{abstract}

El dibujo que La novela luminosa diseña a lo largo de su desarrollo tiene tres aristas claras: la muerte, las experiencias luminosas y la melancolía cotidiana. Como veremos, la experiencia luminosa es como un suplemento de vida, una sobrevida. Por su intensidad, su forma arbitraria y con frecuencia delirante, el pathos celebratorio con el que se recibe su acaecimiento, la ubican entonces en el extremo opuesto de la muerte.

En el medio tenemos esa melancolía cotidiana que forma la masa más sustancial del texto, donde dominan "la rutina y las adicciones", cierta obscenidad, la abulia y el humor. Vemos a Levrero emprender proyectos de reforma sin mucha convicción, y los diarios son todos un proyecto de poner en movimiento la escritura, ejercicios de disciplina, pero este moderno Oblomov, sin embargo, sólo confía íntimamente en intervenciones milagrosas del espíritu y descree íntimamente de cualquier proceso, creativo o no, en el que esté involucrada la voluntad o el "yo consciente”. El ser humano sólo es una canal de trasmisión de los caprichos del espíritu: "El amor, el espíritu es un soplo eterno, que sopla a través de los tubos vacíos que somos nosotros" (Leviero, La novela 473). La escritura está en manos de su Daimon, y la felicidad en manos del azar o de "Dios". Los diarios son, eso sí, rigurosos análisis de este estado letárgico así como intentos de evocar "la memoria del alma" sin el concurso de la cual todo esfuerzo, toda escritura y toda experiencia resultan inútiles.

La gente incluso suele decirme: “Ahí tiene un argumento para una de sus novelas”, como si yo anduviera a la pesca de argumentos para novelas y no a la pesca de mí mismo. Si escribo es para recordar, para despertar el alma dormida, avivar el seso y descubrir sus caminos secretos; mis narraciones son en su mayoría trozos de la memoria del alma, y no invenciones. (Levrero, Discurso vacío 122)

Levrero llamó a las novelas La ciudad (1970), París, y El lugar, la Trilogía involuntaria, mucho después de que estuvieran escritas porque se dio cuenta de que las tres obras tenían a la ciudad como núcleo y podían verse como una trilogía. Las novelas no fueron escritas para llegar a formar esa figura: surgió espontáneamente.

Revista Iberoamericana, Vol. LXXVIII, Núm. 241, Octubre-Diciembre 2012, 1043-1065
ISSN 0034-9631 (Impreso) 
Y este desarrollo semi-consciente caracteriza el acto de escribir de Levrero. Por un lado, desde Diario de un canalla la escritura de estas crónicas íntimas se propone explícitamente como un medio de perfeccionamiento personal, o del "alma” y a ratos hasta de salvación a través de la voluntad y la disciplina. El primero empieza con la confesión de que una ciudad corrupta lo ha hechizado, alejándolo de sí mismo, y explica que recurre a la escritura como curación y búsqueda. El discurso vacío es un intento de mejorar la personalidad a través de ejercicios caligráficos, invirtiendo el principio de la grafología. Escribir una caligrafía regular e inteligible le ayudará, según el autor del diario, a mejorar su carácter. Como se sabe, asumir el diseño de la personalidad y el cuidado de sí a través de la disciplina y la escritura es un programa ético y estético del Helenismo que fascinó al último Foucault. En Levrero aparentemente se trata de recuperar el control de la vida, hacerse “dueño de su destino”, pero este propósito pagano no encaja del todo con la inclinación mística de Levrero. Aparentemente los diarios se escriben buscando un equilibrio, una forma de salubridad, pero este propósito de salud no es el del "yo" consciente o el de la personalidad sino la búsqueda de un "yo" profundo que se encuentra alienado de sí mismo. Por lo tanto, escribir, asumir la disciplina de escribir, para Levrero significa crear la posibilidad de una distracción y de una entrega, y no la de un control. Crear un espacio donde se instale su Daimon y éste emprenda su intuitivo juego. Ese demonio personal o "espíritu travieso" que le dictará las palabras puede aparecer o no. Como se sabe la palabra evoca las ambiguas deidades griegas donde se confundían el genio o el alma del individuo (y su destinación) y eran intermediarias entre los dioses y los hombres. Su acción es independiente de la voluntad individual y en Levrero representan una fuerza caprichosa del inconsciente. La contradicción entre voluntad de control y Daimon, entre objetivos explícitos e inclinación del alma, producen ese estilo desgarrado característico del sujeto dividido.

Todo lo finalmente escrito en estos diarios es el producto de no haber podido cumplir con los objetivos que explícitamente lo justificaban. El resultado son textos que se le han escapado de las manos al narrador, el producto de desvíos, de tentaciones inconscientes. La sustancia literaria de aquel discurso que se pretende vacío es justamente su no buscado contenido. Pretendiendo escribir sobre nada continuamente se distrae y "a su pesar", cuenta cosas. Podríamos completar la imagen del discurso vacío con la del discurso involuntario. Esta es la otra paradoja en los diarios de Levrero. En El discurso vacío hay una tensión entre la disciplina caligráfica, el propósito explícito de escribir sobre nada y lo que de hecho se relata. El relato surge de esta indisciplina, como infracción involuntaria sobre el proyecto original, como desvío productivo. En La novela luminosa el objetivo confeso es "poner en marcha la escritura" (21) y escribir sobre cualquier cosa, para crear el hábito. Pero no es la novela, no es el proyecto de la beca. La tensión que tematiza el diario, sin embargo, es esta permanente postergación de la obra que debería haber sido el objetivo principal. Sabemos que esas páginas están en el lugar

\footnotetext{
Revista Iberoamericana, Vol. LXXVIII, Núm. 241, Octubre-Diciembre 2012, 1043-1065 ISSN 0034-9631 (Impreso)

ISSN 2154-4794 (Electrónico)
} 
de algo en lo que no se avanza mientras los plazos se acortan. Se trata entonces de una escritura desarrollada como rodeo y postergación. Una escritura terapéutica que tiende a desdibujarse como “obra” y a realizarse como síntoma. Síntoma de una ausencia: la del espíritu, la de la voluntad misma, la de la luz. Fundidas la escritura y la vida en el diario, toda su existencia parece movida por inercias: “Quisiera poder encaminar mejor mi vida, mis horarios, mis intereses. Pero cada vez lo veo más difícil, más remoto. Me muevo por puros automatismos” (424).

Lo que se hace experimentable en esa tensión entre pereza y escritura, o escritura de la pereza en esa lucha sistemática y productivamente perdida contra el abandono, es, como hemos visto, la propia sustancia del tiempo. Pero también y sobre todo se pone en escena un "yo" sin autoridad ni poderes que lejos de dirigir su escritura emerge como su subproducto. En ese recurrente desvío el "yo” ficcional de Levrero relata con radical sinceridad esa cotidianidad llena de propósitos frustrados y claudicaciones y de esta manera se expone y se pone en juego como un "yo" errante y vacilante que buscándose, sólo consigue extraviarse o sumergirse en fuerzas superiores a su capacidad de control. El sujeto que emerge de La novela luminosa es un sujeto “involuntario”, a la vez narcisista e inoperante, cuyo emplazamiento es el de la espera y la rememoración. Su única función es permitir que surja “el texto preexistente” (Silva Olazábal 47) de lo impersonal subconsciente, donde se albergarían imágenes arquetípicas.

El sujeto narrador, débil, solitario, aislado, se nos va revelando como un ser que aguarda en un territorio desvastado. Este aguardar es sin duda, un aguardar abierto a la posibilidad de que algo, la escritura, el amor, la visión, acaezca, pero es una espera sin mucha convicción. Toda la democrática absorción del diario, su meticuloso registro de actividades, su introspección, sus triviales indagaciones, su analítica de los sueños, su documentación fiel y humorística de días y de noches, tienen su figura exacta en esa paloma "viuda” elegida por él mismo para representar su Stimmung dominante:4 la desolada azotea donde una paloma muerta no cesa de descomponerse y otra da vueltas en su torno, como esperando una improbable resurrección. Esos son los rodeos del "Diario de la beca"; este aguardar y custodiar en la vecindad de un cadáver. El "yo" ficcional de Levrero se va presentando como un impotente y angustiado custodio del espíritu que no termina nunca de desfallecer. ${ }^{5}$

${ }_{4}$ Prueba del estilo de Levrero, de su humor des-realizador, es que no sólo tematiza el carácter simbólico de los pájaros (ave=espíritu) (271) sino que también lo parodia, cuando después de comentar estas apariciones simbólicas de los pájaros en su vida, nos cuenta, relativizando, que una paloma se coló en su casa por la ventana y que ésta fue una experiencia nada espiritual y más bien desagradable.

5 La idea de que La novela luminosa es "una tozuda búsqueda del espíritu", aunque en forma diferente a la aquí presentada, la ha tratado Ignacio Echeverría en un hermoso ensayo: "Levrero y los pájaros" (Echerverría 95).

Revista Iberoamericana, Vol. LXXVIII, Núm. 241, Octubre-Diciembre 2012, 1043-1065
ISSN 0034-9631 (Impreso) 2154-4794 (Electrónico) 
TEORÍA GLOBAL DE LA VIDA

La certeza de que no tendré tiempo de integrarme a ese lugar $[\ldots]$ y a esa gente [...] soy extranjero en todas partes. A veces hasta en mi casa... (248)

El uso del diario como máquina de narrar tiene obviamente distintas consecuencias. El diario no procede reconstruyendo un pasado ya concluido. No hay, no puede haber, una retrospección general que selecciona y jerarquiza como en la autobiografía o en las memorias, ni una historia previamente concebida o escuchada y que selecciona los materiales ordenándolos según la necesidad o la estética de la trama, como en la novela. En el diario se supone que se anota el día a día de una vida sin anticipaciones ni retrocesos, o sea, carece de un diseño capaz de ofrecer concentradamente la figura acabada de una vida.

Al igual que Borges, Levrero es un devoto de la novela policial (aunque del policial norteamericano), pero su modo de concebir el relato está en las antípodas del maestro argentino. Borges ve en el policial un ejemplo de elegancia formal, un relato "lúcido y limitado”, “donde profetizan los pormenores” como dice en "El arte narrativo y la magia”.

Es decir, lo opuesto a la novela psicológica cuya causalidad supone "infinitas operaciones” (Borges 172). Para Levrero la novela policial es una adicción y no un modelo narrativo. No aspira a la narración simétricamente cerrada sobre sí misma, donde sólo figuren los ingredientes necesarios, sino al discurso deshilachado que se extiende caprichosamente y se interrumpe sin aviso.

Lo que en Levrero recuerda al género policial es quizás el talante investigador de sus personajes. Podríamos decir que, como en otros textos de Levrero, el narrador en primera persona se presenta en La novela luminosa como un indagador compulsivo (ehistriónico) para quien la investigación de estructuras harto complejas es una forma de evasión adictiva, similar a la adicción al juego. Tiene la necesidad visceral (y culpable) de entender y manipular o mejorar los programas (robados) que incorpora a su computadora, procesos que se viven como una apuesta fuerte y su culminación exitosa como un "orgasmo" (275); o de llegar a dominar la lógica de los juegos electrónicos (248). Invierte mucho tiempo en observaciones de entomólogo y pasa horas analizando el funcionamiento de un hormiguero porque necesita saber exactamente adónde va cierta hormiga (246) como necesita saber también la "línea imaginaria" que traza un hombre cualquiera cuando va a su trabajo (247). Ante el encuentro social con un grupo de personas desconocidas siente aprehensión e incomodidad pero al mismo tiempo una irreprimible necesidad de cartografiar los lazos que unen y relacionan a todas ellas (247). Tarea imposible donde las haya que le dejan una melancólica añoranza, la “de algo perdido, [la] de un mundo que nunca podré conocer” (247). Por otra parte, toda arquitectura avizorada, toda trama

\footnotetext{
Revista Iberoamericana, Vol. LXXVIII, Núm. 241, Octubre-Diciembre 2012, 1043-1065 ISSN 0034-9631 (Impreso) 
resuelta, dejan de interesarle, como dejan de interesarle las novelas policiales una vez leídas. Esta obsesión por el funcionamiento de las redes que se entretejen en un sistema infinito de relaciones y cuyas dimensiones son imposibles de abarcar para una persona, desemboca quizás en su “Teoría global de la vida”:

[...] una gran estación de ferrocarril, de la cual están partiendo continuamente trenes que llegarán o no a destino, que volverán o no a la estación, portando cada uno de ellos un pequeño yo ansioso, con su rostro amarillento pegado a la ventanilla [...] Saber combinar la marcha de los trenes en su conjunto es el arte de escribir como sería el arte de vivir saber combinarlos en la vida real [...]. (505)

Una vida, una novela, es una red inabarcable de trayectos y temporalidades.

La inclinación al análisis, a perderse en él, es una constante en Levrero y se complementa con la pereza que le impide mantener el rumbo de los proyectos que concibe y anuncia. El diario de la beca inicia segmentos autobiográficos pero no concluyen. Sugiere o avanza revelaciones importantes que se postergan o no se dilucidan. Para ser verdadero, el relato tiene que operar sobre lo fragmentario, tiene que ser fragmento y fracaso. El recurso al diario personal como su particular máquina de narrar, facilita quizás el registro de esta vaga sensación de “incompletud”, de experiencia segmentada y fugaz.

El "yo" de Levrero se refiere algunas veces al diario como a "esta investigación de mí mismo” o un “monólogo narcisista” (169). La digresión indagadora que en la retórica antigua era la parte móvil del discurso y sostenía la oralidad, Levrero la usa para sostener la escritura también desde cierta espectacularidad, al ponerla en primer plano. Hay efectivamente algo entre provocador y narcisista en esa puesta en escena de la (no) escritura. Y es que la lucha incesante y titánica por el espíritu, por “avivar el alma dormida”, que el narrador se propone (siempre sin éxito, según él) como misión de la escritura, es una lucha que se libra en o dentro del propio “yo”, con éste y contra éste.

El diario permite también dos operaciones esenciales: la incorporación heterogénea de diversos temas y formas de escribir y la representación de una específica temporalidad. Dominado por una única voz personal La novela luminosa se nutre de distintos géneros discursivos (el relato, el ensayo, la confesión, el “panfleto”, la digresión) para contarnos las impresiones de lector y convicciones existenciales de su autor; su condición de paciente, de adicto, de habitante de la ciudad, para contarnos su dieta o analizar sus sueños o los de otros. Su enfoque particular de la narración cronológica puede compararse con las tomas de plano fijo en el cine, donde lo que determina el contenido de las imágenes es que estas aparezcan o se crucen en el recuadro o espacio controlado por la cámara. En el caso del diario este recuadro sería la fecha y la hora que enmarcan lo relatado. Si en el Discurso vacío el propósito era "escribir sobre nada”, en La novela luminosa parece que se trata de escribir todo. No son los acontecimientos (acontecimientos relevantes para el relato) los que la narración debe ubicar en el tiempo sino que es el tiempo, la

Revista Iberoamericana, Vol. LXXVIII, Núm. 241, Octubre-Diciembre 2012, 1043-1065
ISSN 0034-9631 (Impreso) 
fecha y la hora, en la que se escribe el que determina lo que se relata. Esto incluye escribir también que no ha pasado nada o que hoy no se tienen ganas de escribir. Así es como hay fechas en las que leemos frases como: "Sí, otra vez se me hicieron las seis de la mañana. Pero por lo menos no entré a Internet. Me pregunto qué estuve haciendo durante todas estas horas" (78). Cuando el diario se interrumpe unos días y el diarista tiene que reconstruir de memoria lo sucedido en esos días ausentes, la escritura no puede evitar, según Levrero narrador, ser "fraudulenta" (282). La autenticidad del diario entonces, estaría también en esa fidelidad a contar lo inmediato, o sea, en la casi simultaneidad entre escritura y suceso. Así el sábado 13 de enero de 2001, a las cuatro de la mañana leemos únicamente los siguiente: “¡JA,JA,JA! ¡He derrotado al verano! Tengo aire acondicionado. Lo festejé con medio vaso de vino. Estoy borracho.” (306).

La modalidad del diario, a partir de "Diario de un canalla", El discurso vacío y La novela luminosa, es un dispositivo de incorporación de materiales innobles o aparentemente intrascendentes que le permiten al autor crear una relación indiferenciada con los objetos. El diario es, sin duda, uno de los géneros literarios con más oportunidades para la impureza. Al ser su cometido el atrapar el presente en su fugacidad como pasado recientísimo y tener al “yo" como autor y lector privilegiado, se amplía considerablemente la posibilidad de viajar entre lo microscópico y lo gigantesco, lo soñado y lo vivido, lo íntimo y lo público, lo cotidiano y lo trascendente, lo circunstancial y lo eterno. Esto puede trastocar con relativa facilidad los límites implícitos que separan lo literario de lo no literario en una determinada época. Podríamos decir incluso que el diario mismo como género podría definirse como un límite indiscernible entre lo uno y lo otro.

Esto permite una operación de extrañamiento en la medida en que la indiferenciación, a ratos, nos hace percibir el mundo cotidiano de Levrero como una multiplicidad sin sentido. De cualquier manera, esta tendencia al registro igualitario de lo múltiple hace que el texto remueva y trastorne lo que Jacques Rancière ha llamado la "división de lo sensible” (Rancière 27-58) ${ }^{6}$ y ésta es una de las características que hacen de Levrero un "raro" contemporáneo.

EL DIARIO Y LA MUERTE

“Laplantita que me había regalado Julia murió del todo”(263)

El diario evidentemente supone también una temporalidad específica. Homogeneiza los días y las noches sin importar lo decisivo o lo trivial de ciertos momentos, únicamente diferenciados por las fechas que tiene asignadas. El narrador vive en el espacio reducido de su departamento luchando con problemas domésticos de diversa índole, dando

6 Según Rancière el arte es político en la medida en que interviene en la experiencia sensorial. Este siempre se inscribe en un sistema de inclusiones y exclusiones que es el corazón de la política.

Revista Iberoamericana, Vol. LXXVIII, Núm. 241, Octubre-Diciembre 2012, 1043-1065 ISSN 0034-9631 (Impreso) ISSN 2154-4794 (Electrónico) 
una que otra clase de taller literario y visitado por amigas que lo sacan a pasear. Estas actividades no consiguen disimular una temporalidad fundamentalmente estática, donde el tiempo aparece sustraído de todo montaje teleológico.

Lo que se registra es una vida donde se articulan trivialidad y desasosiego, o lo que Levrero llama a veces “angustia difusa” y otras “depresión”. La novela luminosa tiene mucho de "novela oscura”, en el sentido de que toda la parte dedicada al "Diario de la beca” es la descripción de una vida experimentada como impropia o inauténtica, un estado de impotencia cuyo mejor anuncio está ya escrito en el Epílogo a El discurso vacío:

Cuando se llega a cierta edad, uno deja de ser el protagonista de sus acciones: todo se ha transformado en puras consecuencias de acciones anteriores. Lo que uno ha sembrado fue creciendo y de pronto estalla en una especie de selva que lo rodea por todas partes [...] y no queremos salir porque sabemos que no hay donde salir, porque la selva es uno mismo y una salida implicaría alguna clase de muerte. Y si bien hubo un tiempo en que se podía morir cierta clase de muerte en apariencia inofensiva, hoy sabemos que aquellas muertes eran las semillas que sembramos de esta selva que hoy somos. (168)

Y es entonces la vecindad de la muertelo que condiciona en todo momento la escritura. El puro encadenamiento de los días va destacando gradualmente la propia sustancia del tiempo e, inevitablemente, provoca una dolorosa consciencia de transitoriedad. Porque aún cuando un diario íntimo puede suponer el registro de un período determinado en la vida de su autor, como es el caso del diario de Santomé en La tregua y el propio “Diario de la beca”, la estructura del diario como modo de contar es potencialmente infinita porque la rige el calendario y supone y permite la adhesión ad infinitum de nuevos días o nuevas horas. Pero el diario es también personal y por tanto se conjuga con una vida humana concreta. El tiempo del diario personal es el del plazo limitado de una vida que se relata en su contingencia, fragilidad y finitud. La sustancia del diario es la propia inmediata vivencia. Se puede decir entonces que su estructura temporal es intrínsecamente escatológica porque supone la muerte como su interrupción lógica. Es en la muerte donde el diario personal alcanzaría su límite absoluto. Pero en la forma precisamente de la interrupción porque a diferencia de la biografía, el momento de la muerte misma, lo más íntimo de un ser, es lo único que no puede ser contado. Nadie puede contar su propia muerte, salvo como anticipación profética. En torno a ese hueco oscuro gira el auto-relato. A diferencia de la biografía, la autobiografía o las memorias, el diario es siempre inconcluso. El diario personal es el género de la anticipación de la muerte.

Lo que va dibujando esta relación con un tiempo presente sin distancias retrospectivas es la sensación de que entre esta sucesión de hechos cotidianos y la muerte no va quedando nada y es justamente la nada, como desasosiego metafísico, lo que se insinúa desde el principio como "angustia difusa”. En el registro de distintos “ahoras” sometidos al orden implacable de las fechas, el diario personal instala la angustia de la finitud en la

Revista Iberoamericana, Vol. LXXVIII, Núm. 241, Octubre-Diciembre 2012, 1043-1065
ISSN 0034-9631 (Impreso) 
base de las vivencias que relata. Escribir simultáneamente al vivir, tomar esa distancia de las ocupaciones habituales para sentarse a contarlas poniéndolas sobre el papel, nos confronta a la vacuidad esencial de una serie de operaciones cotidianas y a la pregunta por su sentido profundo. El género diario también es, entonces, un dispositivo para la angustia.

La temporalidad de la angustia sólo conoce dos momentos relevantes: el tiempo puro y la muerte. La “angustia difusa” anticipa la muerte, pero ésta por el momento no se presenta. "Donde hay angustia la muerte está cerca, próxima, inmediata” (GarridoMaturano 313) pero el tiempo puro dura, no termina de pasar, es sencillamente "todo el tiempo” (ídem). Y entonces tenemos esa sensación de espera involuntaria. ¿Espera de qué? Espera de la muerte que acabe con la angustia o de un tiempo redentor, un instante que mientras dure sea eterno, y que en Levrero no sería otra cosa que la experiencia luminosa.

La novela está plagada de referencias directas e indirectas a la muerte: los dolores que lo paralizan en la calle y que el narrador explica al principio como la consecuencia de dolencias cardíacas pero que resultan no ser otra cosa que accesos de pánico, o sea, miedo indeterminado, somatizado, a la muerte. Recibe mensajes que lo informan del fallecimiento de viejos amigos, llamadas telefónicas que son como heraldos negros. La única planta de su balcón muere y Chl se muestra cada vez más esquiva. En la parte llamada "La novela luminosa", texto escrito unos 10 años antes, el narrador aduce una próxima operación de vesícula para apresurar su texto que se concibe como un eventual testamento, porque "uno nunca sabe” (462).

Incluso la relación con sus patrocinadores parece teñirse de acentos fúnebres. La beca Guggenheim se insinúa por momentos como un contrato fáustico que concede tiempo y ocio a cambio de un rendimiento específico que debe pagarse al final. Ese tiempo de ocio concedido no le pertenece en el fondo al autor del diario sino al "señor Guggenheim,” la figura cómica que Levrero crea para personalizar esta instancia de dependencia.

Estimado Mr. Guggenheim, espero que sea consciente de los esfuerzos, registrados en este diario, para mejorar mis malos hábitos, al menos algunos de ellos, al menos en la medida en que estos hábitos me impiden dedicarme plenamente al proyecto de escribir esa novela que usted tan generosamente ha financiado. Ya ve usted que hago todo lo que está humanamente a mi alcance, pero tropiezo una y otra vez contra ese montón de escombros que yo mismo, alguna vez he volcado en mi camino. (96)

Estimado Mr. Guggenheim: Creo que usted ha malgastado su dinero [...] Mi intención era buena pero lo cierto es que no sé qué se ha hecho de ella. Ya pasaron dos meses: julio y agosto, y lo único que he hecho hasta ahora es comprar esos sillones (que no estoy usando) y arreglar la ducha (que tampoco estoy usando). El resto del tiempo lo

Revista Iberoamericana, Vol. LXXVIII, Núm. 241, Octubre-Diciembre 2012, 1043-1065 
he pasado jugando con la computadora. [...] Muchos saludos y recuerdos a la señora Guggenheim. (86)

Así, el "señor Guggenheim” se perfila como una deidad generosa pero temible que concede un tiempo impropio para culminar una obra inconclusa como el año divino que durante unos segundos humanos Dios le concedió a Jaromir Hladik frente al pelotón de fusilamiento para que completara su drama en verso Los enemigos, en "El milagro secreto" de J. L. Borges. Sólo que el yo narrador del diario de la beca, menos voluntarioso o menos disciplinado que aquel judío de Praga, malgasta su precioso tiempo en juegos de computadora y en febriles e inútiles insomnios. Tiempo divino y aprovechado el de Jaromir, tiempo donado y malgastado el de Levrero. El primero es un tiempo concluido por la reanudación del fusilamiento, un tiempo perfecto con el que Borges cierra la narración y su tensión, su paréntesis secreto. El segundo, el del "Diario de la beca”, es un tiempo inconcluso, imperfecto, un paréntesis que no se cierra, abierto a la incertidumbre, y a la vez un demasiado tarde. ¿Cómo terminar un diario que aspira a ser novela sin involucrar la propia muerte?

Antes de dormir pensaba que por su estructura de novela ya debería estar terminado, pero su calidad de diario no me lo permite, sencillamente porque hace mucho tiempo que no sucede nada interesante en mi vida como para llegar a un final digno. (431)

Finalmente el diarista considera su propia muerte como uno de los finales más apropiados y propone este fragmento entrecomillado:

Estoy cansado de todo. La vida no es más que una carga idiota, innecesaria, dolorosa. No quiero sufrir más, ni llevar más esta miserable vida de rutinas y adicciones. Apenas cierre estas comillas, pues, me volaré la cabeza de un tiro. (432)

Pero a continuación deshecha esta salida dramática al problema del fin del diario (que según él le daría lectores) porque no sería verdadera (y ni siquiera sabe como manejar un arma). Incluso confiesa sentirse relativamente cómodo y hasta feliz en su vida maniática, a pesar de una "dominante depresiva” (433). El diario termina como empezó, registrando hechos triviales y resumiendo los muchos días en que se lo abandonó. Hay sí un epílogo donde se da información sucinta sobre el estado en el que quedaron los distintos temas abiertos en el diario: los programas digitales, las palomas, Chl y el amor, el robo de software, los electricistas, los antidepresivos y hasta la problemática vinculada al yogurt con vitamina C. Muy importante en este sentido es el epígrafe de J.D. Salinger "En el fondo mi mente siempre se ha rehusado a aceptar cualquier tipo de final” (559) y sobre todo la aseveración de Levrero que le sigue: "Un diario no es una

Revista Iberoamericana, Vol. LXXVIII, Núm. 241, Octubre-Diciembre 2012, 1043-1065
ISSN 0034-9631 (Impreso) 
novela, a menudo se abren líneas argumentales que luego no continúan [...] este libro, en su conjunto, es una muestra o un museo de historias inconclusas” (559).

Habría que decir que el tiempo narrativo de Levrero es el de un presente inacabado. Es un tiempo de angustia y una modalidad que tiene la virtud de contaminar el mundo de la vida; porque, al dejar abierto su período, permite más fácilmente que el mundo de la ficción se continúe en el imaginario del lector y hace posible ese cruce entre la ficción del relato y la ficción de la vida al que se refirió Paul Ricoeur en Educación y política (201).

LA MATERIALIDAD DE LA ANGUSTIA

...miedo a caer entre esos materiales desagradables.

Hay a lo largo de la novela un registro pormenorizado de la relación del narrador con los objetos que lo rodean, sean estos muebles o aparatos o instrumentos domésticos, sean espacios transitables o documentos. La lucha diaria con los objetos domésticos abarca una larga serie: sus lapiceras, su incómoda forma, el grosor inadecuado de la tinta y sus efectos en la caligrafía, sus problemas con el radiador de aire, las dificultades culinarias, los efectos colaterales de los medicamentos, la computadora y sus comportamientos, los inconvenientes con la electricidad, los apagones, el angustioso trámite de renovar la cédula de identidad, la pesadillesca travesía urbana, son algunas de estos tours de force del diarista con las dificultades prácticas de la vida. Todo manejo con artefactos o instrumentos supone en Levrero una rutinaria exasperación, un fastidioso o heroico enfrentamiento de igual a igual con las cosas. Ante los objetos siente pereza o una adicción incontrolable. No responden simplemente a su voluntad, no parecen estar a mano. La computadora, que el diarista maneja con cierta pericia, pasa de ser una prolongación tecnológica de la mente a convertirse en una máquina infernal. El narrador necesita una difícil autodisciplina para no caer en la absorción fascinada que provoca su mecanismo combinatorio. Sometido a la tentación de los programas, los juegos, las fotos pornográficas, e incapaz de domesticar el instrumento que lo ha sometido, el diarista siente que ha perdido "su otrora espléndida vida interior" (166) y ha quedado reducido al aburrimiento del oficinista. A veces, sin embargo, la lucha con la computadora es épica: "Me voy a dormir sintiendo una gran satisfacción. También diría que estoy emocionado. Fue una lucha difícil pero por segunda vez [...] pude modificar un programa” (328).

Hay una escena quizás más significativa dada la importancia que en esta novelabotiquín tienen los medicamentos: el narrador toma un nuevo antidepresivo (la mayoría le hacen mal) y nos relata que la lucha del medicamento contra la depresión se manifiesta en una oscilación del ánimo que lo hace entusiasmarse y cansarse sucesivamente. Como consecuencia, se levanta del sillón y se sienta alternativa y repetidamente, según

\footnotetext{
Revista Iberoamericana, Vol. LXXVIII, Núm. 241, Octubre-Diciembre 2012, 1043-1065 ISSN 0034-9631 (Impreso)

ISSN 2154-4794 (Electrónico)
} 
predomine o no el efecto de la droga sobre la depresión (252). Esta relación chaplinesca que el sujeto narrador despliega con los objetos en esta novela es contraria al entretejido funcional que se supone es el sentido último de los utensilios. En la confianza en que los aparatos, los artefactos y los utensilios nos responderán, nos sumergimos en el automatismo y en la indiferencia pero en la incomodidad frente ellos "se anuncia el mundo" (Heidegger 88).

La angustia difusa de Mario Levrero se expresa como permanente inadecuación con el mundo. Se mueve entre una colección de objetos desobedientes, fascinantes y desalmados que aparecen en su opacidad y van minando la cotidianidad como automatismo, como familiaridad, transformándola en espacio abierto, ambiguo y peligroso.

En este sentido podemos decir que en La novela luminosa asistimos a una virtual materialización de la angustia donde los objetos no son prolongaciones útiles de la voluntad ni desaparecen en el horizonte de confianza que supone el ser de los utensilios. Llaman la atención hacia sí mismos, resistiéndose a la manipulación y apareciendo en su condición de objetos radicalmente otros, radicalmente extraños

Como vimos, en el triángulo formado por los extremos de la muerte, la angustia cotidiana y la experiencia luminosa, el narrador espera a ciegas la resurrección del espíritu, o de su espíritu personal, pero no lo hace al margen de las cosas sino atravesando la severa facticidad de la existencia. ${ }^{7}$

Por otra parte, vivir inadecuadamente, al margen de los horarios de la ciudad, entregándose a actividades inútiles, dedicarse maniáticamente a la computadora o encerrarse en la trama de un policial, forman un paradójico método, una estrategia fatal que genera la angustia y con ella la condición de posibilidad de una apertura:

Sigo atado a la lectura de novelas policiales y a la computadora, pero las novelas policiales están comenzando a aburrirme y a exasperarme, y en lo que respecta a la computadora más bien tiendo a jugar, a hacer cosas inútiles y a preocuparme por detalles insustanciales. Estos focos de angustia me interesan; por ahí tiene que haber una salida. (403)

En el último tramo de la novela, las cien páginas dedicadas al recuento de experiencias luminosas, se establece una relación completamente distinta con la materia. Los objetos se abren a una percepción profunda y cobran una vida insospechada. Las experiencias luminosas son también una redención de los objetos mismos que adquieren entonces virtudes completamente ajenas a los fines que los justifican. Baste mencionar los ejemplos de unas uvas providenciales que lo acercan a Dios y más notablemente un

7 Me refiero a la concepción de facticidad como caída y ruina que posibilita la iluminación del ente en una dialéctica de mostración y ocultamiento. Giorgio Agamben ha estudiado las ambigüedades de este concepto en Heidegger: Questions ouvertes (67).

Revista Iberoamericana, Vol. LXXVIII, Núm. 241, Octubre-Diciembre 2012, 1043-1065
ISSN 0034-9631 (Impreso) 2154-4794 (Electrónico) 
semáforo que es el punto de partida para una de estas experiencias. En la ciudad "de cuatro dimensiones" (498), se distinguen los afectos en las cosas: "Comencé a distinguir los matices de tristeza de ciertos tubos de neón cuando se reflejan en ciertas veredas o la alegría fugaz de algún reflejo inesperado.” (498). Es como si bajo el régimen de lo luminoso, los objetos mismos fueran signos de un texto divino que hay que leer al modo del astrólogo y no del usuario.

LA EXPERIENCIA LUMINOSA

Debo advertir que los hechos que forman parte de esta dimensión [ignorada] no siempre son asimilables a experiencias luminosas. Los tipos macanudos pueden tener su lado siniestro, incluso ser totalmente siniestros, $y$, sin embargo, por ese lado siniestro sobredimensionado, valer la pena. (512)

El "Diario de la beca” y "La novela luminosa” propiamente dicha representan dos temporalidades distintas: una lenta y desesperada y otra retrospectiva, de recuperación o rescate. Es después de la lectura de las últimas cien páginas, encabezadas por el mismo título que preside la novela entera, que podemos contraponer el "Diario de la beca" a "La novela luminosa" y constatar que la cotidianidad desganada del primero adquiere todo su significado desde las páginas vibrantes de la segunda. Todo el proyecto de los diarios se relaciona según Levrero con un "recuperar su alma" o un "despertar el alma dormida” y para él, como hemos visto, esta recuperación es una recuperación de sí mismo, de las fuerzas reprimidas del "inconsciente" y, en definitiva, del Daimon de la escritura. Al comenzar la parte de "La novela luminosa" el yo narrador dice que debe escribir dos novelas: una luminosa y otra oscura. Unas líneas más adelante, en un extraño salto temporal, cuenta que quemó los borradores de esta última (453). Sin embargo es plausible que el "Diario de la beca" sea, o se haya convertido, en aquella novela oscura. Al final del diario, el autor dice que un posible título alternativo, para el diario sería el de "una única y eterna madrugada" (447), es decir, un período oscuro e insomne, el de las horas inapropiadas de la noche donde un solitario noctámbulo espera algo que no termina de llegar. Ambos textos, el oscuro y el luminoso, cubrirían juntos la sustancia "espiritual" de una vida, lo que haría de La novela luminosa la "biografía de un alma” (Onetti 13), es decir el programa de escritura que Juan Carlos Onetti declaró en El pozo por boca de Eladio Linacero en $1939 .{ }^{8}$ La conexión entre estas dos novelas de insomnios, memorias oníricas y esperas, debería estudiarse a fondo.

8 "Me gustaría escribir la historia de un alma, de ella sola, sin los sucesos en que tuvo que mezclarse, queriendo o no". Juan Carlos Onetti, fragmento de El pozo (13).

ISSN 0034-9631 (Impreso) 
Las situaciones luminosas de Levrero son tan ecuménicas como su estilo: un perro oliendo en el pasto los rastros de otro le sugieren que el futuro es una forma del presente (456); unos ojos verdes apenas entrevistos se transforman a posteriori en una mirada ejemplar de "manso amor impersonal" (471); una intensa experiencia sexual y una renuncia sexual igualmente intensa engendran "un hijo no carnal (462)"; el hallazgo improbable de un racimo de uvas abandonado en una parra parece sellar un "pacto con Dios" (518); frente a un semáforo de 18 de julio se descubre un insólito azul en el cielo de Montevideo. También son experiencias luminosas la leche de unos pechos de mujer (465); el insólito comportamiento de una hormiga; una vivencia parapsicológica; la anticipación profética de un sueño; el roce infraleve de las alas de un ángel. ${ }^{9}$

Es inútil buscar en Levrero preferencias por una doctrina o método establecido para sus pesquisas espirituales, estéticas o teológicas. La misma apertura irreverente e indiscriminada para todos los materiales que integran sus narraciones, la tiene también para sus especulaciones metafísicas. El narrador busca una confirmación en las ciencias y en la religión, pero también en formas esotéricas o para-científicas del conocimiento.

\begin{abstract}
Investigué, como dije, desordenada y azoradamente en materiales espiritistas, ocultistas, psicoanalíticos, religiosos y científicos, y logré saber que existía realmente algo a lo que podía llamarse Dios si uno quería, aunque también podía admitir otros nombres; en cualquier caso, era algo que superaba mi capacidad de percepción y de comprensión, pero había sí algo viviente y trascendente, algo que implicaba una multidimensionalidad del universo. También supe que había extrañas formas de comunicación con ese algo, y que esas formas nunca eran iguales a sí mismas y que no podía acceder a ellas a mi antojo. (545)
\end{abstract}

Es evidente que la experiencia luminosa excede la enciclopedia y no puede ser explicada con los conceptos al uso. Tampoco puede ser evocada voluntariamente, apenas presentida. Pero existen formas de comunicación con esta dimensión extraordinaria de la vida. Hay símbolos arquetípicos que anuncian su inminencia (los pájaros), estados semiconscientes que nos dejan sus reminiscencias (los sueños), hechos que confirman su existencia (fenómenos parapsicológicos o telepáticos), formas de contacto humano que la evocan (el amor, el deseo), estados de ánimo que negativamente la representan (la angustia, la depresión), y hay lenguajes hospitalarios para lo luminoso (los de la religión y el delirio).

El contacto profundo con un ser amado, por ejemplo, hace posible leer el vértigo del tiempo concentrado en un rostro.

9 La descripción que hace Levrero de ese misterioso roce en la iglesia es sustancialmente idéntico al que hace Duchamp relativo al concepto de infraleve. (Véase: M. Duchamp, 1998). Muchas de las experiencias luminosas mencionadas en la novela pueden leerse como sutilísimas emanaciones de la materia que sólo unos pocos pueden captar.

Revista Iberoamericana, Vol. LXXVIII, Núm. 241, Octubre-Diciembre 2012, 1043-1065
ISSN 0034-9631 (Impreso) 2154-4794 (Electrónico) 
Sucedía que de pronto yo comenzaba a ver variaciones en el rostro de la persona que tenía junto a mí. La mayoría de las veces, el rostro variaba como si fuera retrocediendo rápidamente en el tiempo, y en lugar de ver ante mí, por ejemplo, una mujer de cuarenta años, veía a una niña de seis [...] Mucho me ha dado que pensar al respecto un cuadro de Velázquez, La madona del espejo; mirándolo bien, se pueden advertir estas variantes temporales en el rostro reflejado en el espejo oval [...] la juventud, la vejez y la muerte. (480)

Este último ejemplo de percepciones singulares del tiempo no es todavía una experiencia luminosa. Forma parte de los avisos, las señales que hablan de la existencia de una dimensión desconocida. Abandonarse a ellas es peligroso para la salud mental y la supervivencia en la ciudad, pero dejarlas incrementa los estados depresivos del narrador (481). Se trata entonces de vivir en la vecindad de los sueños reveladores: permanecer alerta a sus señales, exponerse a ellas. Se trata de darle una oportunidad a la locura. ("Mi auténtica función social es la locura” anuncia en la página 481). La recuperación terapéutica de Chl, por ejemplo, la ha convertido en una mujer más sana, pero también inmune al espíritu.

Chl era un ser completamente distinto del que es hoy. Hoy se muestra como una joven común y corriente, casi diría vulgar, con gustos vulgares y actividades vulgares, o al menos comunes y corrientes. En cierto sentido es una persona más sana y quizás más feliz. Cuando la conocí sufría de frecuentes depresiones, durante las que no conseguía hablar. Vivía largos lapsos de silencio, revertida en sí misma. También muy a menudo tenía sueños prodigiosos; cada uno de esos sueños era casi una novela [...] los personajes que aparecían formaban parte de un mundo diferente, quizás arquetípico. En aquel tiempo llegué a sospechar que en la tierra había seres de otro planeta y que Chl era uno de ellos. [...] Los fenómenos paranormales entre nosotros eran frecuentes. (377)

El narrador prefiere instalarse en la vecindad del misterio: vivir al margen de la vulgaridad diurna o la funcionalidad social es una forma de provocar al espíritu. Para poder experimentar la presencia divina hay que arriesgarse.

A pesar de la ciencia ficción y los fenómenos paranormales y las alusiones a Yung (o precisamente por ello), hay siempre un trance religioso en estos momentos que aluden a un misterio tan próximo como raramente accesible. No se trata de ninguna religión positiva aunque al final del libro el narrador decida convertirse al catolicismo. Se trata más bien de religiosidad en tanto relación natural con la dimensión tenida por sagrada de la existencia. En la modernidad lo divino abandonó las instituciones eclesiásticas y los lugares oficiales del culto. Dios dejó de ser una figura antropomórfica y la religiosidad se transformó en una experiencia. Al sujeto autoconsciente kantiano de la ilustración le es imposible captarla porque es racionalmente ininteligible y porque la dimensión sagrada de la existencia no se capta, se padece. La experiencia religiosa se funda en la

\footnotetext{
Revista Iberoamericana, Vol. LXXVIII, Núm. 241, Octubre-Diciembre 2012, 1043-1065 ISSN 0034-9631 (Impreso) 
presencia latente de Dios como radical heterogeneidad respecto del mundo y los seres humanos. Hay toda una tradición filosófica y teológica moderna que discute el lugar exacto de esta experiencia de Dios (que para algunos es experiencia de la nada). Entre ellos Schleiermacher, Kierkegaard, William James, Rudolf Otto y Marti Buber. ${ }^{10}$ En sus versiones más actuales, la idea de que el ser humano es algo más que una rutina de apetitos cotidianos, tecnología y supervivencia y de que existen experiencias en radical heterogeneidad con la vida utilitaria y cosificada de la modernidad, se puede rastrear en distintos lenguajes filosóficos y en conceptos (en otros planos tan diferentes) como el Ereignis de Heidegger, la experiencia aurática de Walter Benjamin, lo sagrado de Bataille, lo real de Lacan, lo abierto de Agamben y el concepto de acontecimiento en Badiou.

Podríamos decir que a pesar de sus diferencias esenciales, estos conceptos se sostienen en la diferencia ontológica entre ser y ente y en consecuencia entre verdad y opinión. La mayoría de ellos intentan articular o practicar una distancia frente a los dispositivos ideológicos, tecnológicos o productivos que capturan o condicionan las vidas y los comportamientos del animal humano, obliterando su indeterminación originaria.

En el mundo generado por la literatura de Levrero, el momento luminoso es el nombre de esta distancia. Es un acontecimiento que acaece en el mundo pero en incongruencia con él. Es un cortocircuito que interrumpe el continuo cotidiano normalmente cerrado sobre sí mismo y regido por el hábito y el consenso. Las imágenes luminosas muestran disposiciones espacio-temporales alternativas, modos excepcionales de lo sensible, formas inéditas de comunicación entre los cuerpos y las cosas. Levrero nos habla de un yo subterráneo que afloraría en un instante de involuntaria percepción extravagante. Como en la experiencia mística, en Levrero el sujeto es capturado, poseído por una imagen emplazada en una zona de indeterminación entre lo visible y lo invisible, lo personal y lo impersonal. Para entrar en ella, el "yo" consciente (el del hábito y la rutina) debe ser desplazado por otro más originario. Los efectos de lo luminoso constituyen un implícito cuestionamiento del estatuto de la realidad, una riesgosa invasión de la consciencia.

No me convenía, no le convenía a mi estrecha consciencia percibir a aquella muchacha. Mi vista debía resbalar sobre su agradable superficie. Es posible que haya llegado a pensar “Es hermosa” pero nada más. [...] Recorrí el camino de vuelta hacia mi bicicleta y seguí pedaleando, completamente ajeno a la cosa más importante que me había sucedido en mi vida. (472).

Y la mirada seguía allí, y la mirada seguía allí, y sigue allí. Y sigue aquí. (...) yo te aseguro que aquella muchacha está viva, y lo estará siempre porque existe una dimensión de la realidad donde estas cosas no mueren [...]. No mueren porque no han nacido ni tienen un dueño ni están sujetas al tiempo y al espacio. No es tu fotografía lo que

$\overline{10}$ Véase para una interesante comparación "La apelación a la experiencia religiosa” de Martin Jay.

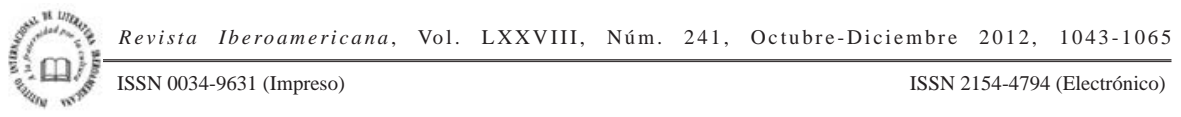


llevo en el alma, muchacha sin rasgos: es tu mirada, justamente lo que no era tuyo, lo que no era tú. (473)

A través de la muchacha es el mundo el que devuelve la mirada por un instante y el sujeto extraviado en un mundo átono y fragmentado experimenta una repentina lucidez. El mundo de lo luminoso es un mundo de cuerpos sutiles que difícilmente se atrapan, como los pájaros, los insectos y las miradas que Levrero inviste como símbolos espirituales e investiga tratando de conservar algo de sus emanaciones una vez que han desparecido. Se trata de instantes de los que sólo queda un rastro confuso, como los restos de un sueño, pero dejan una marca, casi una sabiduría como dice al final de una de estas experiencias:

Pero estoy seguro de haber aprendido secretos de la vida, que después habrán ido aflorando de a poco en los momentos de necesidad. En eso consiste el verdadero aprendizaje: no saber que se sabe, y de pronto saber. (529)

Las experiencias luminosas se almacenan en algún estrato especial de la memoria para surgir en un momento no previsto, como sabiduría involuntaria del pasado. La experiencia consciente sostenía Walter Benjamin, se olvida; la sustantiva (no consciente) se integra en la memoria involuntaria (Costello 126) y aflora en un momento crítico como despertar.

Para el "yo" de la novela estas experiencias no son lo opuesto a la existencia concreta y opaca que se relata en el "Diario de la beca" sino su complemento luminoso. Una ambigua y fortuita apertura hacia lo que Levrero llamó "la cuarta dimensión de la vida”. A veces dependen de una percepción descuidada, que se dejó llevar sin vigilancia, sin contención porque: "La percepción es un acto doloroso, es un acto de entrega, es un acto de desintegración psíquica. Por eso somos cuidadosos en la selección y en los alcances de nuestra percepción” (472).

En la modernidad urbana los múltiples estímulos ponen a prueba la integridad de la conciencia individual. El habitante de la gran ciudad desarrolla una actitud de indiferencia defensiva para eludir la masividad de la vida moderna y sus presiones. Una reflexión que, como se sabe, inició Georg Simmel en $1903^{11}$ y reelaboró después Walter Benjamin mediante los conceptos de Erlebnis y Erfahrung (Buck Morss, Walter Benjamín 69). Entregarse a la percepción asumiendo todas sus consecuencias puede desequilibrar nuestro aparato sensorial, que se defiende de ella neutralizando sus efectos profundos. Para Benjamin esto tiene consecuencias significativas en la forma en que se estructura la memoria y en lo que definió como la pobreza moderna de la experiencia.

${ }^{11}$ En "Die Grossstadte und das Geistesleben” (1903) publicado en español como "El individuo y la libertad. Ensayos de crítica de la cultura”. Barcelona, Editorial Península, 1986.

Revista Iberoamericana, Vol. LXXVIII, Núm. 241, Octubre-Diciembre 2012, 1043-1065 ISSN 0034-9631 (Impreso) ISSN 2154-4794 (Electrónico) 
La relación entre percepción, vivencia y experiencia en Levrero, merecería un análisis más detenido del que podemos hacer aquí.

Las experiencias luminosas tienen una temporalidad propia. Son como irrupciones (una palabra cara a Levrero) de eternidad en el tiempo sucesivo y finito. También excesos infligidos a la normalidad. Vienen de no se sabe dónde a interrumpir el curso de la mera subsistencia y de la agonía cotidiana y arrojan una suerte de luz sobre lo que Levrero llamó el alma. Pero esta luz poco tiene que ver con la inteligibilidad discursiva y mucho con un descalabro lógico y con la irrupción de fuerzas sensibles que no tienen nombre. Son experiencias que sólo pueden ser evocadas frágilmente a posteriori, no en tanto hecho positivo sino en tanto resto o en tanto rastro o trazo fantasmal en el sujeto. Según Levrero, uno de sus nombres es Dios. ${ }^{12}$

Toda la obra última de Levrero consiste en completar la realidad "objetiva” con esa "cuarta dimensión de la vida". La primera correspondería al mundo profano, determinado por un limitado sistema perceptivo y la segunda a un tiempo heréticamente sagrado (en Levrero habría que agregar esotéricamente) donde el sujeto, atravesado misteriosamente por imágenes inéditas, trasciende su mundo concreto y su finitud. Al ser como un relámpago de lo sagrado en la existencia fáctica terminan siendo como iluminaciones profanas. ${ }^{13}$ Toda una colección de objetos anodinos o comunes aparece redimida bajo la condición del acontecimiento prodigioso o "telepático" formando una constelación donde tiempo y espacio se entretejen de manera peculiar. ${ }^{14}$ A veces, cuando la experiencia luminosa se produce, su beneficiario, su víctima, solo puede expresarse en rezos o en himnos.

Lo cierto es que mi estado de ánimo cambió por completo y, sí allí estaba de nuevo esa dimensión que me faltaba siempre, y qué serenidad, qué linda tibieza, qué seguro me

${ }_{12}$ Palabra maestra, ideológica donde las haya. Pero al mismo tiempo es una manera de sustraer el nombre y el lugar de la verdad al circuito de la comunicación "objetiva”, a la circulación del sentido. Dios equivale en Levrero a la nada que hace que todo sea posible. El destino problemático de los nombres de la verdad está expuesto meticulosamente por Etienne Balibar en Nombre y lugares de la verdad. 1995, especialmente p. 66 y ss.

${ }^{13}$ La idea de que si existe redención, un estado utópico de felicidad humana, éste no se dará al final de una evolución natural sino a través de una ruptura, una interrupción, que es de este mundo pero que no puede asimilarse a él, ni durar, es una idea eje en las herejías medievales sobre la humanidad de Cristo, en el misticismo alemán y en el mesianismo judío. La última resonancia de este pensamiento es la teoría del acontecimiento de Alain Badiou. Ver también Scavino, 2007:184 y ss.

14 Así define Walter Benjamin la experiencia del “Aura” en "Pequeña historia de la fotografía”, en Selected Works, II 518-519. En Benjamin el concepto de “Aura” es ambiguo. En algunos textos clásicos tiene valor cultual (y reaccionario), en otros, valor emancipatorio. Nos referimos al último. La imagen dialéctica por ejemplo es, en algún sentido, también la ocasión en que el mundo devuelve la mirada, como en la experiencia aurática.

Revista Iberoamericana, Vol. LXXVIII, Núm. 241, Octubre-Diciembre 2012, 1043-1065
ISSN 2154-4794 (Electrónico) 
siento, qué bien está todo. Gracias, C; gracias C por tu paseo y tu playa y tu secreto. Pueden venir nomás a sacarnos de aquí a balazos. Pueden soltar los perros. ¿Quién va a ser tan idiota y malgastar su tiempo en el temor? Dispara de una vez tu pistola, canallita de cartón: puedes matarme pero yo soy eterno. Esta roca me ama. Esta playa me ama. Este cielo, este viento, estas gaviotas, estos guijarros. ¡Dios! Bendito seas, y bendita tu Creación, por los siglos de los siglos, amén. Y bendita tu ley del amor. (529)

Lo luminoso es una excepción, una incongruencia que aparece en el límite entre el sentido común y el delirio. Pero la epifanía es un instante efímero, siempre en retirada. Un salto se ha dado, algo se ha avizorado allá arriba; un destello feliz o tremendo del que ahora no queda nada. Sólo cabe serle fiel tratando de vivir bajo su régimen durante el tiempo que dure su efecto o recuperándolo, por ejemplo, en la lucha que la escritura debe mantener consigo misma para nombrarlo. En el proceso de recoger narrativamente el recuerdo original éste se transforma, se reelabora o se redescubre. Incluso aparecen momentos cuya luminosidad había pasado inadvertida (como el redescubrimiento del inconfesado amor por la prostituta $\mathrm{H}-501$ ). La tarea de escritura entonces, como en el psicoanálisis, produce efectos en la memoria, la constituye y la transforma. En el epílogo a El discurso vacío Levrero narrador menciona un sueño donde aparece "el secreto de la alquimia” (169). Es la última frase de la novela. La auténtica alquimia en Levrero es la que procesa la escritura misma. ${ }^{15}$ Es en la escritura donde finalmente un hecho confuso del pasado, que es como soñado, puede llegar a transformarse (alquímicamente) en un hecho significativo para el presente, es decir, transfigurarse en experiencia.

La literatura del último Levrero es una búsqueda de fórmulas o nombres que expresen estas radicales singularidades que presuntamente lo han asaltado en momentos de su vida. Por un lado, mediante el recurso a lo luminoso, la ficción de Levrero intenta pensar la discontinuidad de un mundo que se presume continuo y lineal. Por otro, las visiones de La novela luminosa proponen un reordenamiento poético de la realidad. Aparecen como verdades del alma que no se calculan ni se deducen ni se revelan, más bien ocurren, acaecen en el rapto místico. Sus nombres nunca figuran en el diccionario vigente: tienen que ser forzados poéticamente, y esa es una de las formas en que la literatura piensa una verdad. ${ }^{16}$

Esto ocurre a veces reflotando conceptos rancios o términos ya desgastados por la costumbre que Levrero transfigura literaria, alquímicamente, devolviéndoles su capacidad de estremecimiento.

${ }^{15}$ El tema de la alquimia está presente en otros textos de Levrero. Véase el artículo de Noelia Montoro Martínez (2006).

16 "La filosofía reconocerá que toda nominación de un acontecimiento, que convoca a la retención de lo que desparece, todo acto de nombrar la presencia acontecimiental, es de esencia poética.” (Alain Badiou, 2009:72).

Revista Iberoamericana, Vol. LXXVIII, Núm. 241, Octubre-Diciembre 2012, 1043-1065 ISSN 0034-9631 (Impreso) ISSN 2154-4794 (Electrónico) 
Hacia el final de la novela el narrador cuenta la historia de su conversión al catolicismo de la mano de Cándido. Cándido es un rudimentario e histriónico sacerdote de barrio, que hace trampas pueriles jugando al ajedrez (547-548) y carece aparentemente de toda inquietud trascendental. Investido de su dignidad sacerdotal, sin embargo, resulta un recordatorio de la presencia divina, de la posibilidad de una fe. El narrador hace con él su primera comunión y tiene la última experiencia luminosa en la ceremonia de la misa. El fragmento de su conversión es particularmente jocoso y a la vez pasional. Resulta extremadamente significativo en la medida en que es la única oportunidad en la que el yo narrador concibe la posibilidad de entregarse a un ritual, a una experiencia colectiva de trascendencia. Implícitamente, el fragmento habla de la necesidad de una ceremonia en un mundo donde todo ritual sólo puede ser una farsa. La modernidad se ha constituido precisamente excluyendo la posibilidad de una auténtica ceremonia compartida (Badiou, Five Lessons 147).

En La novela luminosa, la conversión, el trance de la misa y la primera comunión, son escenas altamente paródicas. Pero esto no excluye una experiencia (religiosa) radical. La trillada imagen de la virgen le provoca un llanto involuntario por todas las mujeres amadas cuyos rostros empiezan a desfilar en su interior (553) y durante la comunión experimenta el roce levísimo pero imborrable de las alas de un ángel (556).

Cuando volvió a la iglesia a comulgar, nada de esto volvió a suceder. Las formas en las que se perciben las experiencias luminosas son irrepetibles. Ninguna doctrina o lenguaje específico puede preverlas o contenerlas. Sus lugares de aparición no están establecidos, no son conocidos ni rastreables; son bordes, zonas sensibles de discontinuidad. Es en esa zona de indeterminación y desobediencia donde todo pensamiento auténtico empieza. Es allí donde Levrero sitúa el horizonte de su escritura.

BiBLIOGRAFÍA

Agamben, Giorgio. Heidegger: Questions ouvertes. París: Osiris/Collège International de Philosophie, 1988.

Arlt, Roberto. "El escritor fracasado”. El jorobadito. Buenos Aires: Losada, 1997.

Badiou, Alain. Pequeño manual de inestética. Buenos Aires: Prometeo, 2009. Five Lessons on Wagner. Londres: Verso, 2010.

Balibar, Etienne. Nombres y lugares de la verdad. Buenos Aires: Nueva visión, 1995. Benedetti, Mario. La tregua. Madrid: Cátedra, 1998.

Benjamin, Walter. Selected Writings. Cambridge: Harvard UP, 1999.

Blanchot, Maurice. La conversación infinita. Madrid: Arena Libros, 2008.

Borges, Jorge Luis. Prosa Completa. Barcelona: Bruguera, 1985.

Buck Morss, Susan. Dialéctica de la mirada. Madrid: Visor, 1995. Walter Benjamin, escritor revolucionario. Buenos Aires: Interzona, 2005.

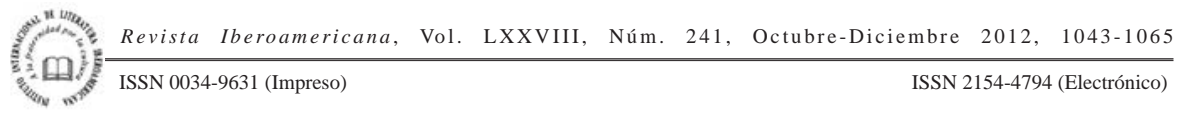


Costello, Diarmuid. “Aura, rostro, fotografía, releer a Benjamin hoy”. Walter Benjamin: Culturas de la imagen. Alejandra Ulslenghi, comp. Buenos Aires: Eterna cadencia, 2010. 126.

Echeverría, Ignacio. “Levrero y los pájaros”. Conversaciones con Mario Levrero. Pablo Silva Olazábal. Montevideo: Trilce, 2008. 93-102.

Duchamp, Marcel. Notas. Madrid: Tecnos, 1998.

Fernández, Macedonio. Museo de la novela de la eterna: (primera novela buena). Tomo 6. Obra completa. Buenos Aires: Corregidor, 1975.

Garrido-Maturano, Ángel. Sobre el abismo. Buenos Aires: Adriana Hidalgo, 2010.

Heidegger, Martin. El ser y el tiempo. Madrid: Fondo de Cultura Económica, 1980.

Hernández, Felisberto. "Diario de un sinvergüenza”. Obras completas. México: Siglo XXI editores, 1983. 245-264.

Jay, Martin. Cantos de experiencia. Variaciones modernas sobre un tema universal. Buenos Aires: Paidós, 2009.

Levrero, Mario. La novela luminosa. Barcelona: Debolsillo, 2009. El discurso vacío. Barcelona: Debolsillo, 2009-2

Montoro Martínez, Noelia. "La alquimia de la creación en Mario Levrero". Hermes criollo. Revista de crítica y de teoría literaria y cultural V/10 (2006): 115-123.

Onetti, Juan Carlos. El pozo. Para una tumba sin nombre. Madrid: Mondadori, 1990.

Ranciere, Jacques. El malestar en la estética. Buenos Aires: Capital intelectual, 2011.

Ricoeur, Paul. Educación y política. Sobre el tiempo. Guidi Indij, ed. Buenos Aires: La marca editora, 2008. 199-201.

Scavino, Dardo. La filosofía actual. Pensar sin certezas. Buenos Aires: Paidós, 2007.

Silva Olazábal, Pablo. Conversaciones con Mario Levrero. Montevideo: Trilce, 2008.

Simmel, Georg. "El individuo y la libertad”. Ensayos de crítica de la cultura. Barcelona: Editorial Península, 1986. 247-261.

Verani, Hugo. "Mario Levrero o el vacío de la posmodernidad”. Hermes criollo. Revista de crítica y de teoría literaria y cultural V/10 (2006): 125-133.

\footnotetext{
Revista Iberoamericana, Vol. LXXVIII, Núm. 241, Octubre-Diciembre 2012, 1043-1065 
